\title{
Comparison of quality characteristics of Platycodon grandiflorum according to steaming and fermentation
}

\author{
So-Young Kim ${ }^{1 *}$, Ye-Jin Lee ${ }^{2}$, Dong-Sik Park ${ }^{3}$, Haeng-Ran Kim ${ }^{3}$, Yong Sik Cho ${ }^{1}$ \\ ${ }^{1}$ Fermented Food Science Division, National Institute of Agricultural Science, Wanju 55365, Korea, \\ ${ }^{2}$ NUMED Company, Seoul 02440, Korea, \\ ${ }^{3}$ Functional Food Division, National Institute of Agricultural Science, Wanju 55365, Korea
}

\section{증숙 및 발효에 따른 도라지의 품질특성 비교}

\author{
김소영 ${ }^{*} \cdot$ 이예진 ${ }^{2} \cdot$ 박동식 $^{3} \cdot$ 김행란 $^{3} \cdot$ 조용식 ${ }^{1}$ \\ ${ }^{1}$ 국립농업과학원 발효식품과, ${ }^{2}$ 주식회사 뉴메드, ${ }^{3}$ 국립농업과학원 기능성식품과
}

\begin{abstract}
This study was designed to improve the sensory characteristics and mitigate the bitter taste of Platycodon gradiflorum. It was aimed at investigating the qualitative properties of fermented $\boldsymbol{P}$. gradiflorum after repeated steaming and drying treatments. $P$. gradiflorum was heated for $2 \mathrm{hr}$ at $95^{\circ} \mathrm{C}$, being the first and third treatments compared afterwards. Lactobacillus plantarum, at a concentration of $10 \%$, was used as starter culture. As a result, the third steaming process and the addition of starter improved the physical and chemical properties of $P$. gradiflorum i.e., crude saponin and total polyphenol contents increased significantly. Moreover, $P$. gradiflorum steamed three times and fermented by $L$. plantarum showed the higher overall preference score. Our results indicated that the three-time steaming and drying was an effective manufacturing process for the production of high-quality fermented $\boldsymbol{P}$. gradiflorum. Lactic acid-fermented $\boldsymbol{P}$. gradiflorum also could have a potential use as a valuable resource for the development of functional products.
\end{abstract}

Key words : fermentation, Platycodon gradiflorum, Lactobacillus plantarum, steaming, sensory preference

\section{서 론}

최근 외식 및 식자재 산업의 발달로 전처리 공정을 거친 신선 농산물의 소비가 확대되고 있고, 현대인들의 식생활 패턴의 변화로 인하여 건강한 식품을 찾는 소비자가 증가하 고 있다. 특히 우리나라의 경우 홍삼을 비롯한 다양한 기능 성 소재들이 포함된 건강기능식품에 대한 수요 증대로 인해 원료 자체를 단순히 증숙, 건조하는 형태를 벗어나 다양한 제조공정을 거쳐 기능성을 높인 소재를 탐색하고자 하는 시도가 이루어지고 있다. 현재 인삼과 홍삼을 이용하여 다

*Corresponding author. E-mail : foodksy@korea.kr Phone : 82-63-238-3263, Fax : 82-63-238-3843

Received 2 November 2015; Revised 10 November 2015; Accepted 17 November 2015.

Copyright (c) The Korean Society of Food Preservation. All rights reserved.
양한 형태의 소재를 발굴 또는 개발하는 연구가 상당한 부분을 차지하고 있고, 일부에서 도라지가 여러 가지 약리 효과를 가지고 있다는 연구가 밝혀지면서 인삼 및 도라지의 소비량이 증가하게 되어 재배면적이 확대되고 있다.

도라지(학명: Platycodon grandifforum(Jacq) Nakai)는 길 경(桔梗, Platycodi Radix)이라고도 하는데 초롱꽃과 (Campanulaceae)의 여러해살이풀로 7 8월에 종 모양의 흰 색 또는 자주색 꽃이 피는데 뿌리는 먹거나 거담이나 진해 의 약재로 쓴다(1). 도라지는 예로부터 약재로 쓰여 왔기 때문에 다양한 기능성 연구를 통해 그 효능이 이미 밝혀져 보고되어 있다. 도라지 추출물의 면역력 증진, 항암 및 항균 효과 등의 기능성 연구(2-4)를 비롯하여 건조방법, 저장방 법 및 저장기간에 따른 도라지 뿌리 중 platycodin $\mathrm{D}$, polygalacin D 및 deapioplatycodin D 등의 사포닌 함량의 변화에 대한 연구도 보고되어 있다(5,6). 그 밖에도 도라지 의 좋은 기능을 부가하여 쿠키, 식혜 등 식품가공에도 활용 
한 연구와 도라지를 Aspergillus oryzae 곰팡이로 발효하여 항비만효과를 보고하는 등 다양한 분야에서 연구가 활발히 수행되고 있다(7-9). 그러나 도라지의 다양한 효능에도 불 구하고 도라지 자체의 강한 쓴맛으로 인하여 소비자 기호도 가 나뉘기 때문에 껍질을 탈피하여 찬물로 쓴맛을 우려내어 제거하거나 익히는 등 조리과정을 거쳐 보다 많은 사람들이 섭취할 수 있도록 하고 있다. 아직까지 도라지의 쓴맛 성분 은 명확히 밝혀지지 않았으나 platycodin 등의 사포닌류인 것으로 알려져 있는데(8) 이들 성분을 제거 또는 낮추기 위해서 생도라지를 증숙, 발효하여 만든 홍도라지 내에 함 유된 사포닌이 가수분해되어 도라지의 맛과 냄새 등의 기호 도가 상승했을 뿐만 아니라 기능성도 높아졌다는 연구(10) 가 보고되어 있다. 그러나 유산균 등 발효미생물을 이용하 여 도라지의 유용성분을 증대하거나, 발효시킨 도라지의 기능성 평가 실험을 통해 효능을 밝힌 연구, 이러한 발효 도라지를 이용한 가공식품 개발에 관련된 연구는 찾아보기 힘들다.

유산균은 젖산발효를 하여 식품의 부패를 방지하며 항균 물질을 분비하여 식중독 억제를 돕고, 사람의 장내 $\mathrm{pH}$ 를 낮추어 장내 부패세균의 증식을 억제하는 등의 긍정적 효과 를 가진다. Lactobacillus plantarum은 우리나라 발효식품에 서 분리되는 대표적인 유산균으로 최근에 면역 기능과 관련 하여 다양하게 관련 분야에서 사용되고 있으며 사람이나 동물의 장 건강에도 깊이 관여하므로 매우 중요한 미생물 중 하나로 중요시 되고 있다(11). 특히 김치, 된장 등 발효식 품에서 분리되어 프로바이오틱스(probiotics) 유산균으로 서 체내 유용한 생리 활성 작용을 한다고 알려지면서 이 균에 대한 관심이 더욱 높아지고 있다(12). 이에 유산균의 발효기술을 도라지와 같은 약효를 가지고 있는 식물 소재에 접목함으로 도라지의 품질을 증진시켜 소비확대와 부가가 치를 높이기 위한 가공기술 개발이 절실히 필요하다.

따라서 본 연구에서는 탈피하지 않은 채 도라지를 증숙 및 유산균 발효공정을 통해 건조도라지를 제조하고 이들 과정에서 도라지의 성분 변화 및 쓴맛 등 맛에 미치는 영향 을 분석하여 다양한 도라지 가공제품을 개발하기 위한 산업 적 기초자료를 제공하는 한편, 유산균으로 발효한 도라지 의 기능성 소재로서 활용가치를 높이고자 하였다.

\section{재료 및 방법}

\section{실험재료}

도라지 시료는 경기도 이천시 소재의 재배농가에서 2011 년 수확하여 3 년간 저온 저장된 3년근 도라지를 제 공받아 사용하였다. 실험에 사용한 도라지는 평균 $15.43 \mathrm{~mm}$ 굵기 (상부로부터 $30 \mathrm{~mm}$ 위치 측정)의 것만을 선별하였다.

\section{증숙 및 발효도라지 제조}

발효도라지 제조공정은 선행연구 $(13,14)$ 를 참고하여 Fig. 1에 나타낸 과정을 거쳐 증숙 및 발효도라지를 제조하 였다. 도라지의 증자는 $95^{\circ} \mathrm{C}$ 에서 2 시간 동안 실시하였고, 열풍건조는 식품건조기(LD-918BH, L'equip, Seoul, Korea) 를 사용하여 $60^{\circ} \mathrm{C}$ 에서 6 시간 동안 수행하였는데, 이와 같은 증자와 열풍건조 과정을 1 3회 반복하였다. 발효도라지 제 조를 위해 유산균 중 Lactobacillus plantarum(주식회사 Tobico) 동결건조 분말 $\left(1 \times 10^{10} \mathrm{CFU} / \mathrm{g}\right)$ 을 구입하여 생리식 염수로 $10 \%$ 유산균 침지액을 만들어 일정시간 담갔다가 꺼내고, 무처리군은 생리식염수에 증숙도라지만을 침지시 켰다가 건져내었다. 유산균을 접종한 도라지와 무처리 도 라지는 각각 알루미늄호일 용기 $(145 \mathrm{~mm} \times 195 \mathrm{~mm} \times 60 \mu \mathrm{m})$ 에 담아 배양기(MCL-20A, SNT Inc., Daejeon, Korea)에서 $30^{\circ} \mathrm{C}$ 에서 5 일간 발효시켰고, 이 후 $20^{\circ} \mathrm{C}$ 에서 숙성과정을 거친 후 $60^{\circ} \mathrm{C}$ 에서 3 시간 열풍건조하여 증숙 및 발효도라지 를 제조하였다.

건조된 시료는 분쇄기(Shinil, Seoul, Korea)로 갈아 지름 $70 \mu \mathrm{m}$ 이하의 크기의 체망을 통과시켜 균일하게 만들어 $-70^{\circ} \mathrm{C}$ 급속냉동고에서 시험 전까지 보관하여 사용하였다.

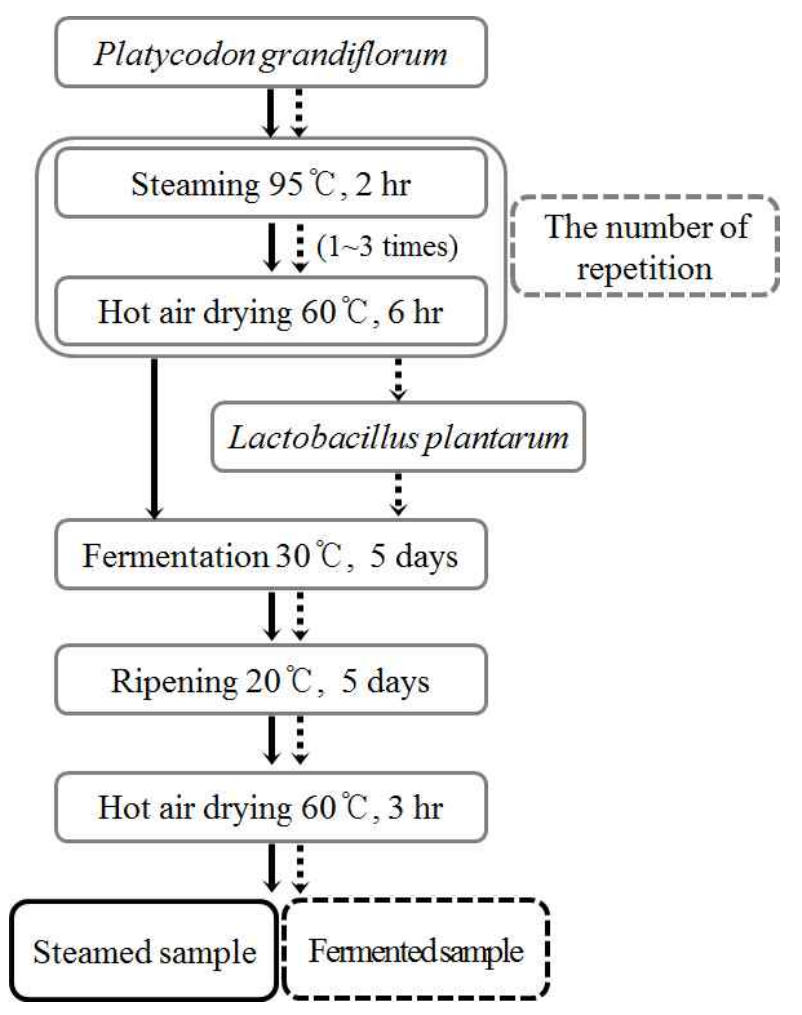

Fig. 1. Method for the preparation of Platycodon grandiflorum according to the steaming and fermentation process.

\section{수분 함량 측정}

$\mathrm{AOAC}$ 법(15)에 의거하여 $105^{\circ} \mathrm{C}$ 상압가열건조법을 이용 하여 수분함량을 측정하였고, 실험은 3 회 반복 수행하여 
평균값을 나타내었다.

\section{$\mathrm{pH}$ 측정}

도라지 분말 $1 \mathrm{~g}$ 에 증류수 $10 \mathrm{~mL}$ 을 가하여 균질화 (PT-2500E, POLYTRON Homogenizer, Kinemarica AG, Luzern, Switzerland) 한 후 filter paper(Whatman, No.6)로 여과하여 얻은 여액을 $\mathrm{pH}$ meter(Mettler-Toledo $\mathrm{AG}$, Schwerzenbach, Switzerland)로 측정하였다. 실험은 3회 반 복 수행하여 평균값을 나타내었다.

\section{색도 측정}

색도는 증숙 및 발효도라지를 색차계(Color i7, X-Rite, Inc., Grand Rapids, Michigan, USA)를 이용하여 측정하였 고, Hunter값의 명도(lightness, L), 적색도(redness, a) 그리고 황색도(yellowness, b) 값으로 나타내었다. 실험은 3회 반복 수행하여 평균값을 나타내었다.

\section{경도 측정}

증숙과 건조 과정을 반복한 도라지의 물러짐의 정도를 평가하기 위하여 물성분석기(Texture analyser, TA.XTplus, SMS, Surrey, UK)를 이용해 경도(hardness)를 측정하였다. 시료는 도라지 중에서 비슷한 크기를 골라 도라지 머리로부 터 $1 \mathrm{~cm}$ 떨어진 부분을 5 회 반복하여 측정한 값으로 평균값 을 구하였다. 경도는 시료를 압착할 때의 힘을 측정한 최대 peak 값을 $\mathrm{g}$ force 단위로 나타내어 평가하였으며, 측정조건 은 trigger force $5.0 \mathrm{~g}$, pre test speed $5.0 \mathrm{~mm} / \mathrm{sec}$, test speed $1.0 \mathrm{~mm} / \mathrm{sec}$, post test speed $5.0 \mathrm{~mm} / \mathrm{sec}$ 로 하였다.

\section{총폴리페놀 함량 측정}

본 실험을 위하여 Folin-Denis 방법(16)을 변형하여 측정 하였다. 시료 $100 \mathrm{mg}$ 를 넣은 $100 \mathrm{~mL}$ 둥근 플라스크에 증류 수를 채우고 초음파(DH. WUC. A22H, DAIHAN-Sci, Wonju, Korea)로 추출하였다. 이 추출액 $1 \mathrm{~mL}$ 을 취하여 $7 \mathrm{~mL}$ 의 증류수를 넣고 $0.5 \mathrm{~mL}$ Folin-Ciocalteu's phenol reagent(Sigma Chemical Co., St. Louis, MO, USA)와 포화 $\mathrm{Na}_{2} \mathrm{CO}_{3} 1 \mathrm{~mL}$ 를 차례로 가하여 실온에서 60 분간 반응시킨 후 $765 \mathrm{~nm}$ 에서 흡광도를 측정하였다. 표준물질로는 tannic acid(Alfa Aesar, Lancashire, England)를 사용하였고, 실험은 3회 반복 수행하여 평균값을 나타내었다.

\section{조사포닌 함량 측정}

조사포닌의 함량은 Shibata 등(17)의 방법과 건강기능식 품공전(18)에 수록된 인삼 - 홍삼성분 분석법을 변형하여 수행하였다. 분말시료 $5 \mathrm{~g}$ 에 $80 \%$ methanol $50 \mathrm{~mL}$ 을 넣고 $70^{\circ} \mathrm{C}$ 수옥상에서 30 분간 2 회 추출한 다음 추출물을 여과지 (No. 2)로 여과하여 감압농축한 다음 증류수 $50 \mathrm{~mL}$ 로 용해 한 후 에테르 $50 \mathrm{~mL}$ 로 2회 추출하여 물층을 회수하고 물포
화 부탄올용액 $50 \mathrm{~mL}$ 로 3 회 추출하여 부탄올층을 회수, 감압농축하여 잔류물은 항량이 될 때까지 $105^{\circ} \mathrm{C}$ 에서 20 분 간 건조하고 데시케이터에서 방냉한 후 무게를 달아 조사포 닌 함량을 구하였다. 추출과정을 거친 후, 실험은 3 회 반복 수행하여 평균값을 나타내었다.

$$
\text { 조사포닌 함량 }(\mathrm{mg} / \mathrm{g})=\frac{\mathrm{A}-\mathrm{B}}{\mathrm{S}}
$$

$\mathrm{A}$ : 물포화 부탄올층을 농축 건조한 후의 플라스크의 무게 $(\mathrm{mg})$ $\mathrm{B}$ : 항량의 빈 플라스크의 무게 $(\mathrm{mg})$

$\mathrm{S}$ : 검체의 채취량 $(\mathrm{g})$

\section{관능 평가}

관능평가는 농촌진흥청 국립농업과학원 농식품자원부 에 재직하는 패널 10 명을 대상으로 진행하였다. 발효 도라 지의 관능검사 항목은 색(color), 향(flavor), 단맛(sweetness), 신맛(sourness), 쓴맛(bitterness), 탄맛(brunt), 질감(texture), 전반적인 기호도(overall preference)의 8 개 항목에 대하여 9점 척도법을 이용하여 평가하였고 그 평균값으로 나타내 었다(8).

\section{통계처리}

본 연구에서 실험값에 대한 통계분석은 SPSS(22.0, SPSS Inc., Chicago, IL, USA) program을 이용하여 ANOVA을 실행하였으며, Duncan's multiple range test 방법과 t-test를 이용하여 평균값 간에 유의수준 $\mathrm{p}<0.05$ 에서 유의성을 검정 하였다.

\section{결과 및 고찰}

\section{증숙 및 발효도라지의 수분과 $\mathrm{pH}$ 변화}

Table 1에 증숙 및 발효 과정을 거쳐 제조한 도라지의 수분 함량과 $\mathrm{pH}$ 변화를 측정하여 그 값을 제시하였다. 수분 함량은 증숙 횟수에 따라 차이를 보였는데, 1 회 증숙한 도라 지의 수분함량은 $13.2 \pm 0.1 \%$ 이었고, 3 회 증숙한 경우는 $7.7 \pm 0.3 \%$ 로 증숙 횟수가 증가할수록 수분함량은 감소하였 다. Lactobacillus plantarum을 접종하여 발효시킨 후 수분함 량의 변화를 관찰하였는데 1 회 증숙한 도라지의 경우에서 는 발효 과정을 거친 도라지 $(11.9 \pm 0.2 \%)$ 가 비발효 도라지 보다 수분 함량이 유의적 $(\mathrm{p}<0.05)$ 으로 낮았고, 3 회 증숙한

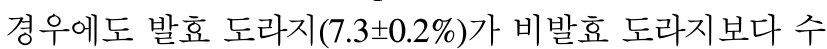
분 함량이 조금 낮았으나 통계적 유의성은 없었다. Lee(19) 의 연구에서 생도라지로부터 흑도라지로 만드는 증숙의 과정 중에 수분 증발이 일어나 이로 인하여 수분함량이 낮아졌다고 설명하고 있어, 본 연구 결과와 비슷한 결과를 보였지만, 발효에 따른 수분 함량의 변화는 명확히 설명할 수는 없지만 접종 유산균이 생육을 위해 도라지의 수분을 
이용하여 낮아진 것으로 추측된다.

발효여부에 따른 도라지의 $\mathrm{pH}$ 변화는 Table 1 에 나타낸 바와 같이 통계적으로 유의적인 값 차이를 보이지 않았지 만, 증숙과 건조 과정을 반복한 횟수가 많은 3회(4.3 4.4)에 서 1회(4.6 4.7)보다 $\mathrm{pH}$ 가 다소 낮았다. 이는 발효시간이 경과함에 따라 $\mathrm{pH}$ 가 감소한다는 연구(20)와 같은 양상을 보였는데, 발효시간이 경과함에 따라 효모에 의해 해당 작 용과 젖산발효에 의해 유기산이 발생되어 낮은 $\mathrm{pH}$ 를 유지 했다는 보고와 유사하지만 증숙 횟수 및 발효에 따른 수분 함량이 낮아짐으로 생긴 차이일 수도 있을 것으로 추측된 다. 하지만 도라지가 증숙 및 발효 등 가공 단계를 거치면서 수분값과 $\mathrm{pH}$ 가 5 이하로 내려가면 유산균 이외의 미생물 번식이 억제되어(21) 저장성을 높이는 효과도 기대할 수 있다.

Table 1. The moisture content and $\mathrm{pH}$ of non-fermented and fermented Platycodon grandiflorum after the $1^{\text {st }}$ and $3^{\text {td }}$ steaming treatments

\begin{tabular}{ccccc}
\hline \multirow{2}{*}{ Characteristics } & \multicolumn{2}{c}{$1^{\text {st }}$ steaming } & \multicolumn{2}{c}{$3^{\text {rd }}$ steaming } \\
\cline { 2 - 5 } & Non-fermented & Fermented & Non-fermented & Fermented \\
\hline Moisture (\%) & $13.2 \pm 0.1^{1)}$ & $11.9 \pm 0.2$ & $7.7 \pm 0.3$ & $7.3 \pm 0.2$ \\
$\mathrm{pH}$ & $4.7 \pm 0.1$ & $4.6 \pm 0.1$ & $4.4 \pm 0.1$ & $4.3 \pm 0.1$ \\
\hline
\end{tabular}

${ }^{1)}$ All values are mean \pm SD.

\section{증숙 및 발효에 따른 도라지의 색 변화}

Table 2에 증숙 및 발효에 따른 도라지의 색변화를 측정 하여 나타내었다. 그 결과 명도(L, lightness), 적색도(a, redness) 및 황색도(b, yellowness) 모두 발효 여부에 따라서 는 유의적인 차이를 보이지 않았지만, 1 회 또는 3회 등 증숙 반복 횟수에 따라서는 명도(L)값은 각각 $33.2 \pm 6.2$ 와 $7.3 \pm 1.5$ 로 증숙횟수가 많을수록 그 값은 유의적으로 낮았 다(p<0.05). 또한 황색도(b) 역시 1 회보다 3 회 증숙한 도라 지가 $56.8 \pm 10.2$ 에서 $12.5 \pm 2.7$ 으로 약 4 배정도 차이로 낮아 져 3회 증숙 도라지를 제품화할 경우 색상에 대한 소비자 기호도를 고려하여야 할 것으로 사료된다. 인삼을 1 회부터 9회 증숙과 건조공정을 반복한 Hong 등(22)의 연구에 따르 면 증숙횟수에 따라 $\mathrm{L}$ 값은 감소를, $\mathrm{a}$ 값은 증가를 나타내었 고, 그리고 $\mathrm{b}$ 값은 증숙을 5 회까지 수행한 인삼의 경우만 증가하였을 뿐 그 이후는 감소하는 경향을 보여, 본 연구에 서 사용한 도라지의 색변화와는 상이한 부분이 있음을 알 수 있었다. 사포닌 함량이 높은 삼, 도라지 등은 강한 쓴맛 때문에 원재료 자체를 이용하기 보다는 가지고 있는 활성성 분의 함량을 증가시키고자 하는 일환으로 고압, 증숙 및 발효 등의 가공방법을 통한 다양한 제품 개발이 이루어지고 있다(14). 이와 같은 가공공정을 거치게 되면 도라지의 구성 성분의 변화를 유발하여 새로운 물질을 만들어 내거나 내부 조직을 파괴하여 유용성분을 용출하게끔 도와주는데, 대체
적으로 증숙과 건조를 반복할수록 도라지 표면의 색깔이 짙어졌다. 일반적으로 가열처리 온도 및 가열시간이 길어 질수록 갈변에 관련된 가용성 성분은 감소하는 반면 갈변물 질의 생성은 증가하는 것으로 알려져 있는데, 가열처리공 정에서 생성된 일부 갈변물질이 항산화활성을 증가시키는 요인이 되기도 한다(22). 이와 같이 갈변물질의 생성은 일부 식품에서는 필수적 현상이며 이 물질들이 노화억제와 같은 작용에 크게 영향을 미친다는 선행 연구들은 많이 보고되어 있다 $(23,24)$.

Table 2. Comparison of the color value of Platycodon grandiflorum according to the number of steaming and fermentation treatments

\begin{tabular}{ccccc}
\hline \multirow{2}{*}{ Color values } & \multicolumn{2}{c}{$1^{\text {st }}$ steaming } & \multicolumn{2}{c}{$3^{\text {rd }}$ steaming } \\
\cline { 2 - 5 } & Non-fermented & Fermented & Non-fermented & Fermented \\
\hline L & $33.2 \pm 6.2^{\mathrm{al})}$ & $35.6 \pm 5.4^{\mathrm{a}}$ & $7.3 \pm 1.5^{\mathrm{b}}$ & $8.3 \pm 1.7^{\mathrm{b}}$ \\
$\mathrm{a}$ & $30.9 \pm 2.1^{\mathrm{ab}}$ & $28.7 \pm 4.7^{\mathrm{b}}$ & $31.8 \pm 1.9^{\mathrm{a}}$ & $32.6 \pm 1.7^{\mathrm{a}}$ \\
$\mathrm{b}$ & $56.8 \pm 10.2^{\mathrm{a}}$ & $60.3 \pm 9.2^{\mathrm{a}}$ & $12.5 \pm 2.7^{\mathrm{b}}$ & $14.1 \pm 3.0^{\mathrm{b}}$ \\
\hline
\end{tabular}

${ }^{11}$ Mean \pm SD with different letters are significantly different by Duncan's multiple range test at $\mathrm{p}<0.05$.

\section{증숙 및 발효에 따른 도라지의 경도 변화}

증숙 및 발효 과정을 거친 후 숙성까지 완료한 도라지는 최종적으로 $60^{\circ} \mathrm{C}$ 에서 3 시간 동안 건조하였을 때 겉은 딱딱 한 질감을 보였지만, 속은 적당히 축축하여 말랑한 질감을 보여주었다. 이때 사용한 시료들의 경도를 측정하여 Table 3 에 나타내었다. 그 결과 생도라지의 경도가 $2,250 \pm 69 \mathrm{~g}$ 에 서 증숙 과정을 거쳐 도라지의 조직이 물러지고 약해져 1 회 증숙 도라지와 발효도라지의 경우 각각 $548 \pm 20$ 과 $531 \pm 40 \mathrm{~g}$ 를 나타내었으나, 3 회 증숙한 증숙과 발효도라지 의 경우에는 각각 $870 \pm 35$ 와 $911 \pm 25 \mathrm{~g}$ 을 나타내어 증숙과 건조 과정을 반복함에 따라 조직이 조금 단단해짐을 알 수 있었지만 유산균 발효에 따른 경도 차이는 그다지 크지 않았다. Lee(19)의 연구에서 증숙 도라지의 경우 생도라지 를 흑도라지로 제조할 때 견고성이 $1571.89 \mathrm{~g}$ 에서 154.00 $\mathrm{g}$ 으로 약 $1 / 10$ 까지 감소하였다고 보고하고 있다.

따라서 생도라지를 증숙하여 만든 흑도라지는 조직이 물러져서 연한 씹힘성의 특징을 가지고 있어 정과와 같은

Table 3. Textural property of Platycodon grandiflorum after the $1^{\text {st }}$ and $3^{\text {rd }}$ steaming treatments

\begin{tabular}{cccccc}
\hline & \multicolumn{4}{c}{ Samples } \\
\cline { 2 - 6 } & Raw & $\begin{array}{c}1^{\text {st }} \text { steaming } \\
\text { non- } \\
\text { fermented }\end{array}$ & $\begin{array}{c}1^{\text {st }} \text { steaming } \\
\text { fermented }\end{array}$ & $\begin{array}{c}3^{\text {rd }} \text { steaming } \\
\text { non- } \\
\text { fermented }\end{array}$ & $\begin{array}{c}3^{\text {rd }} \text { steaming } \\
\text { fermented }\end{array}$ \\
\hline $\begin{array}{c}\text { Hardness } \\
(\mathrm{g})\end{array}$ & $2,250 \pm 69^{1)}$ & $548 \pm 20$ & $531 \pm 40$ & $870 \pm 35$ & $911 \pm 25$ \\
\hline
\end{tabular}

${ }^{1)}$ Values are mean \pm SD of three replication 
가공 제품 개발이나 유용성분의 추출이 용이함으로 기능성 식품소재 개발에 적합할 것으로 판단된다(25).

\section{총폴리페놀 함량 변화}

Fig. 2에 증숙 및 발효에 따른 도라지의 총폴리페놀 함량 변화를 측정하여 그 값을 나타내었다. 그 결과 도라지를 L plantarum 유산균에 의해 발효하였을 때 1 회 증숙한 도라 지의 총폴리페놀 함량이 시료 $100 \mathrm{~g}$ 당 $33 \mathrm{mg}$ 에서 $40 \mathrm{mg}$ 으 로, 3회 증숙한 경우는 $38 \mathrm{mg}$ 에서 $46 \mathrm{mg}$ 으로 유의적 $(\mathrm{p}<0.05)$ 으로 증가하였고, 또한 증숙의 반복횟수에 따라서 도 유의적인 차이로 증가하는 결과를 나타내었다. 이는 초 기 3 번의 인삼 증숙 처리까지 총 페놀화합물 함량이 2 배 정도 증가하였다는 Hong 등(22)의 연구와 유사하고 또한 건대추의 폴리페놀 함량이 발효 후에 크게 증가함에 따라 발효를 통한 항산화력 증진효과의 가능성을 확인한 Auh 등(26)의 연구결과와도 일치한다. 본 연구에서 사용한 유산 균과 동일하게 홍삼액에 L. plantarum을 접종한 것이 일반 홍삼에 비하여 페놀성 화합물 함량이 유의적으로 높았고 $\mathrm{DPPH}$ 라디칼 소거력이 감소하였다고 Lee 등(27)도 보고한 바 있다. 이와 같은 결과는 일반적으로 가열온도와 처리시 간이 증가함에 따라 추출되는 총 페놀성화합물의 함량이 증가하는 것으로 보고되는데, 이는 결합형 페놀성분이 열 에 의해 유리형으로 바뀌어 용출되거나 고분자가 저분자로 분해되어 그 함량이 증가한 것으로 고찰하고 있다(28).

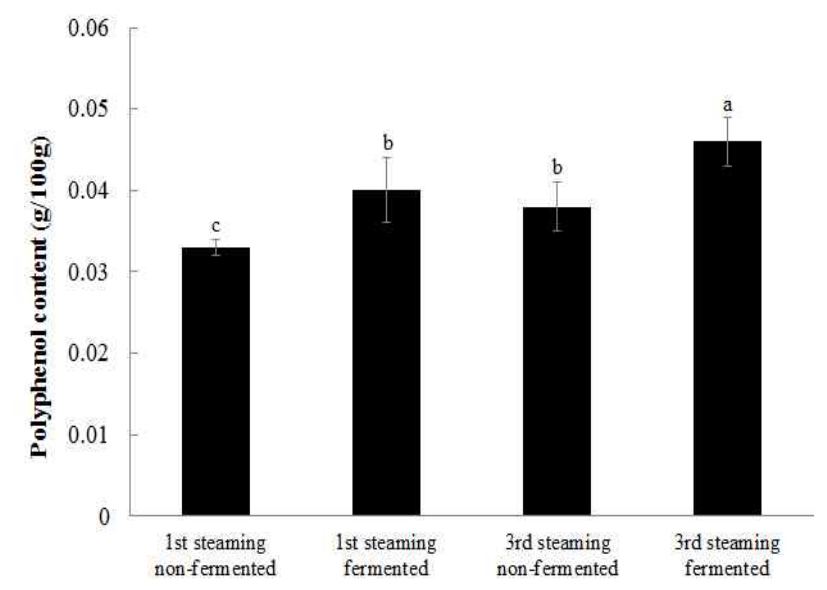

Fig. 2. Changes in total polyphenol content of Platycodon grandiflorum according to the number of steaming and fermentation cycles.

Mean \pm SD with different letters above a bar are significantly different by Duncan's multiple range test at $\mathrm{p}<0.05$.

\section{조사포닌 함량 변화}

사포닌 성분은 주로 인삼, 더덕 및 도라지 등에 함유되어 있는 대표적인 활성성분 중 하나로 이를 구성하고 있는 진세노사이드의 종류에 따라 다양한 생리활성이 보고되고 있다(29). 대다수의 사람들은 사포닌을 분해 흡수시키는데 유용한 세균들이 없어 인삼이나 홍삼을 완전 흡수하기는
어려워, 장내 미생물의 분포 차이로 인한 소화 흡수율 저해 를 막기 위해서 장내 미생물을 이용하여 발효과정을 거쳐 흡수가 용이하도록 하는 연구가 필요하다고 제안하고 있다 (30).

Fig. 3 에 제시한 바와 같이 1 회 증숙 처리한 도라지는 발효 후 조사포닌 함량이 시료 $100 \mathrm{~g}$ 당 $23.4 \mathrm{~g}$ 에서 31.6 $\mathrm{g}$ 으로 $25.9 \%$ 증가하여 통계적 유의성이 나타났고, 3 회 증숙 처리한 도라지 분말은 발효 후 $41.6 \mathrm{~g}$ 에서 $47.1 \mathrm{~g}$ 으로 통계적 유의성은 없었지만, $11.7 \%$ 로 약간 함량이 증가하였다. 따라 서 증숙과 건조 공정을 반복함에 따라 도라지 중의 조사포 닌 함량이 증가한다는 것을 알 수 있었다. 이는 수삼의 증숙 처리 횟수에 따른 조사포닌 함량변화를 살펴본 Hong 등(22) 의 연구 결과에서 증숙 횟수에 따라 조사포닌의 함량이 완만한 증가 경향을 나타내었다는 결과와 유사하다. 흑도 라지 역시 증숙에 의해 사포닌 함량이 $100 \mathrm{~g}$ 당 $4.45 \mathrm{~g}$ 에서 $7.98 \mathrm{~g}$ 으로 2 배 가까이 증가하였다고 보고한 Lee(19)는 증 숙 작용을 통해 세포벽과 분자구조가 파괴되어 사포닌 추출 효율이 증가하여 사포닌 함량이 크게 증가하였다고 판단하 였고, Park 등(31)은 도라지의 사포닌은 steroid와 비당부분 aglycon으로 구성되어 있는데 발효 시 배당체인 사포닌 대 부분이 aglycon에 붙어있는 당부분이 떨어져나가 사포게닌 의 형태로 전환됨으로써 사포게닌의 함량이 증가한 것이라 고찰하였다.

따라서 본 연구 결과를 토대로 도라지 등과 같은 뿌리 식물의 경우 증숙과 발효과정을 거침으로 항산화 활성 등 다양한 생리활성과 관련된 페놀성 물질이 증가되는 것으로 판단된다(14).

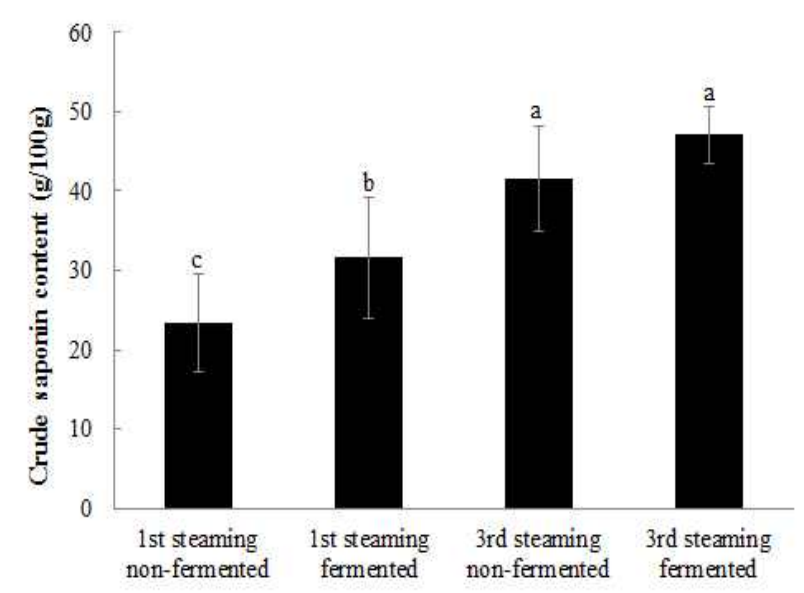

Fig. 3. Changes in crude saponin content of Platycodon grandiflorum according to the number of steaming and fermentation cycles.

Mean \pm SD with different letters above a bar are significantly different by Duncan's multiple range test at $\mathrm{p}<0.05$.

\section{3회 증숙 도라지의 발효에 따른 관능 비교}

$95^{\circ} \mathrm{C}$ 에서 2 시간 증숙하고 6 시간 건조하는 과정을 3 번 반복한 도라지를 발효 여부에 따라 관능 평가를 실시하여 
그 결과를 Table 4에 제시하였다. 그 결과 단맛, 쓴맛, 질감 및 전반적인 기호도 항목에서 비발효 도라지와는 유의적으 로 높은 점수를 나타내었고, 그 외 색, 향미 및 탄맛 항목에 서는 유의성은 없었으나 발효 도라지에서 높은 점수를 보였다.

도라지처럼 주로 쓴맛을 내는 녹차 또한 유용한 생리 활성에도 불구하고, 고유의 쓴맛으로 인해 관능이 저평가 되어 소비자 선호도가 낮아, 다양하게 응용하여 제품화하 는데 어려움이 있어 시장 확대에 한계가 있는 실정이다. 이에 미생물 발효를 통하여 녹차 쓴맛의 주요 성분인 gallate-type catechin을 non-gallate-type으로 변화시킴으로 써 유용성분의 함량 변화 없이 녹차 추출물의 쓴맛 감소와 기호도를 개선할 수 있는 유용미생물 탐색을 한 연구(32)가 있다. 또한 길항작용 특성을 나타내는 Lactobacillus속의 유 산균으로 발효시켜 성분의 변화를 최소화하면서 저장성 증진과 관능적으로 좋은 영향을 주었다는 Kim 등(33)의 연구와 김치 유래 Lactobacillus plantarum을 이용하여 발효 와 열처리를 통해 마늘의 자극적 향미를 개선하고 항산화 활성을 증가시킨 연구(34)도 보고되어 있어 이취, 이미 등 강한 맛과 향을 가진 식물소재에 대한 기호도 향상을 위해 유산균 등 미생물을 이용하여 발효과정을 거치면 관능적 개선 효과를 기대할 수 있다고 판단된다.

따라서 본 연구결과를 토대로 도라지의 강한 쓴맛을 유 산균 발효에 의해 저감화시키는 기술은 전반적으로 좋은 관능 평가를 받아 소비자의 기호도를 개선함으로 도라지의 상품적 가치를 높이는데 기여할 수 있을 것으로 사료된다.

Table 4. Sensory evaluation of fermented and non-fermented Platycodon grandiflorum after the $3^{\text {rd }}$ steaming treatment

\begin{tabular}{cccc}
\hline & $3^{\text {rd }}$ steaming non-fermented & $\begin{array}{c}3^{\text {rd }} \text { steaming } \\
\text { fermented }\end{array}$ & t-value \\
\hline Appearane (color) & $5.04 \pm 1.65$ & $5.15 \pm 1.51$ & -0.26 \\
Flavor (scent) & $5.00 \pm 1.00$ & $5.67 \pm 1.57$ & -1.86 \\
Sweetness & $4.19 \pm 1.44$ & $5.15 \pm 1.35$ & $-2.53^{*}$ \\
Sourness & $4.48 \pm 1.09$ & $4.59 \pm 1.42$ & -0.32 \\
Bitterness & $3.56 \pm 1.22$ & $4.81 \pm 1.49$ & $-3.39^{* *}$ \\
Brunt & $5.26 \pm 1.72$ & $5.78 \pm 1.72$ & -1.11 \\
Texture & $5.04 \pm 1.60$ & $5.85 \pm 1.20$ & $-2.11^{*}$ \\
Overall preference & $4.37 \pm 1.21$ & $5.19 \pm 1.33$ & $-2.35^{*}$ \\
\hline
\end{tabular}

${ }^{1)}$ Data were analyzed by Student's t-test $\left(\mathrm{p}<0.05,{ }^{* *} \mathrm{p}<0.01\right)$.

\section{요 약}

본 연구에서는 도라지의 증숙과 유산균 발효 과정을 통 해 탈피하지 않은 도라지 본연의 쓴맛을 개선하는 공정을 확립하고 제조한 발효 도라지의 품질특성 변화를 조사하였 다. 그 결과 도라지는 발효 여부에 상관없이 증숙 횟수가
1 회에 비해 3회 실시한 경우 수분 함량(11.9 13.2\%와 7.3 7.7\%)과 $\mathrm{pH}$ 값(4.6 4.7와 4.3 4.4)의 범위가 더 낮아졌 고, 또한 증숙 횟수가 3 회 이상 반복될수록 갈변 현상이 더 나타나 도라지의 명도(L)와 황색도(b)의 색변화에 영향 을 나타내었다. 반면 생도라지에 비해 1 회 증숙한 도라지의 경도가 낮아졌다가 3회 증숙과 건조를 반복한 후 조금 단단 해짐을 알 수 있었다. 도라지 중 총폴리페놀 함량은 1 회 증숙한 비발효도라지 시료의 $100 \mathrm{~g}$ 당 $33 \mathrm{mg}$ 에서 3 회 증숙 하여 Lactobacillus plantarum로 발효시킨 후 $46 \mathrm{mg}$ 으로 유 의적인 차이 $(\mathrm{p}<0.05)$ 로 높아져 가열 및 발효 등의 가공공정 을 통해 유용 성분의 증가 효과를 확인하였다. 그리고 도라 지의 조사포닌 함량 역시 1 회 증숙과정을 거친 것 $(23.4 \mathrm{~g})$ 에 비해 3회 실시한 발효도라지에서 $47.1 \mathrm{~g}$ 으로 높은 값을 나 타내, 증숙과 발효 과정을 거쳐 그 함량이 조금 높아짐을 알 수 있었다. 마지막으로 3회 증숙한 도라지의 경우 발효여 부에 따른 관능검사 차이를 조사한 결과 증숙도라지에 비해 발효 후에 단맛, 쓴맛 및 조직감 등이 개선되어 종합적인 기호도가 높았다. 결론적으로 도라지는 증숙횟수가 많고 유산균과 함께 발효하면 도라지 본연의 쓴맛을 개선시킬 수 있고 유용 성분의 함량도 높아짐을 알 수 있었다. 따라서 본 연구 결과를 토대로 기존의 도라지 가공품과 차별화된 제품의 개발에 있어 품질 향상 및 도라지를 이용한 다양한 기능성 발효식품 개발에 활용될 수 있으리라 전망한다. 또 한 유용균주를 이용하여 발효시킨 도라지의 다양한 생리활 성 탐색 연구가 계속적으로 이루어져야 한다고 사료된다.

\section{감사의 글}

본 연구는 2015년도 농촌진흥청 국립농업과학원 농업과 학기술 연구개발사업(과제번호: PJ010927)의 연구비 지원 에 의해 이루어진 연구결과의 일부로, 이에 감사드립니다.

\section{References}

1. Korean Society of Food Science and Technology (2012) Dictionary of food science and technology. Kyomunsa, Gyeonggi, Korea

2. Yoon YH (2012) Increase of immunity against initial cold though the use of balloon flower extracts as tea. MS Thesis. Chosun University, Gwangju, Korea

3. Kim SH, Jeong MJ (2015) Safety and anticancer effects of Platycodon grandiflorum extracts. J Korean Soc Food Sci Nutr, 44, 516-523

4. Kim J (2014) Antibacterial and anti-inflammatory effects of Platycodon grandiflorum extracts. J Dig Conv, 12, 
359-366

5. Lee BJ, Jeon SH, Lee SW, Chun HS, Cho YS (2014) Effect of drying methods on the saponin and mineral contents of Platycodon grandiflorum Radix. Korean J Food Sci Technol, 46, 636-640

6. Lee BJ, Shin YY, Lee SW, Chun HS, Cho YS (2014). Effects of storage methods and periods on root hardness and content of saponin in Platycodon grandiflorum Radix. Korean J Crop Sci, 59, 134-138

7. Jeong EJ, Kim KP, Bang BH (2013) Quality characteristics of cookies containing Platycodon grandiflorum powder. Korean J Food Nutr, 26, 759-765

8. Jeong SI, Yu HH (2013) Quality characteristics of Sikhe prepared with the roots powder of Doraji (Platycodon grandiflorum A. DE. Candolle). J Korean Soc Food Sci Nutr, 42, 759-765

9. Kang YH, Kim KK, Kim TW, Yang CS, Choe M (2015) Evaluation of the anti-obesity activity of Platycodon grandiflorum root and Curcuma longa root fermented with Aspergillus oryzae. Korean J Food Sci Technol, 47, 111-118

10. Park JH (2011) Preparation of red doraji extract and quality properties by extract and aging condition. MS Thesis. Joongbu University, Chungcheong, Korea

11. Korean Society of Food Science and Technology (2008) Encyclopedia of food science and technology. Kwangil Munhwasa, Seoul, Korea

12. Bang JH, Shin HJ, Choi HJ, Kim DW, Ahn CS. Jeong YK, Joo WH (2012) Probiotic potential of lactobacillus isolates. J Life Sci, 22, 251-258

13. Song CH, Seo YC, Choi WY, Lee CG, Kim DU, Chung JY, Chung HC, Park DS, Ma CJ, Lee HY (2012) Enhancement of antioxidative activity of Codonopsis lanceolata by stepwise steaming process. Korean J Medicinal Crop Sci, 20, 238-244

14. Jeon SM, Kim SY, Kim IH, Go JS, Kim HR, Jeong JY, Lee HY, Park DS (2013) Antioxidant activities of processed Deoduck (Codonopsis lanceolata) extracts. J Korean Soc Food Sci Nutr, 42, 924-932

15. AOAC (2005) Official methods of analysis. 18th ed. Association of Official Analytical Chemists, Washington, DC, p 21-22

16. Folin O, Denis W (1912) On phosphotungasticphosphomolybdic compounds as color reagents. J Biol Chem, 12, 239-243

17. Shibata S, Tanaka T, Ando T, Sado M, Tsushima S, Ohsawa T (1996) Chemical studies on oriental plant drugs. XIV. Protopanaxadiol, a genuine sapogenin of ginseng saponins. Chem Pharm Bull, 14, 595-600

18. KFDA (2008) Functional material on health/functional food. Korea Food and Drug Administration. Seoul, Korea, p 44-45

19. Lee SJ (2012) Quality characteristics and physiological activities of black Doraji. MS Thesis. Yeungnam University, Gyeongsan, Korea

20. Jung HH (2011) Quality properties of lactic acid bacteria-fermenting Tteokbokki. MS Thesis. Sunchon National Univerisity, Sunchon, Korea

21. An SM, Lee KA, Kim KJ (2002) Quality characteristics of jeung-pyun according to the leavening agents. Korean J Human Ecology, 5, 48-61

22. Hong HD, Kim YC, Rho JH, Kim KT, Lee YC (2007) Changes on physicochemical properties of Panax ginseng C.A. Meyer during repeated steaming process. J Ginseng Res, 31, 222-229

23. Kim SB, Kim IS, Yum DM, Park YH (1988) Desmutagenic action of sugar degradation products. Korean J Food Sci Technol, 20, 119-124

24. Bailey ME, Um KW (1992) Maillard reaction products and lipid oxidation. Oxford University Press, Oxford, UK, p 122-139

25. Lee SJ, Shin SR, Yoon KY (2013) Physicochemical properties of black doraji (Platycodon grandiflorum). Korean J Food Sci Technol, 45, 422-427

26. Auh MS, Kim YS, Ahn SJ, Ahn JB. Kim KY (2012) Comparision of property changes of black jujube and Zizyphus jujube extracts during lactic acid fermentation. J Korean Soc Food Sci Nutr, 41, 1346-1355

27. Lee HN (2013) Studies on ginsenosides and biological activity of red ginseng extracts fermented with lactic acid bacteria. MS Thesis. Kangwon University, Gangwon, Korea

28. Choi Y, Lee SM, Chun J, Lee HB, Lee J (2006) Influence of heat treatment on the antioxidant activities and polyphenolic compound of shiitake mushroom. Food Chem, 99, 381-387

29. Kim AY (2011) Changes of platycoside of Platycodon grandiflorum by puffing. MS Thesis. Kyunghee Univerisity, Seoul, Korea

30. Bae EA, Park SY, Kim DH (2000) Constitutive $\beta$ -glucosidase hydrolyzing ginsenoside $\mathrm{Rb} 1$ and $\mathrm{Rb} 2$ from human intestinal bacteria. Biol Pharm Bull, 23, 1481-1485

31. Park SJ, Seong DH, Park DS, Kim SS, Gou J, Ahn JH, 
Yoon WB, Lee HY (2009) Chemical compositions of fermented Codonopsis lanceolata. J Korean Soc Food Sci Nutr, 38, 396-400

32. Park SB, Han BK, Oh YJ, Lee SJ, Cha SK, Park YS, Choi HJ (2012) Bioconversion of green tea extract using lactic acid bacteria. Food Eng Pro, 16, 26-32

33. Kim JH, Lee WJ, Cho YW, Kim KY (2009) Storage-life and palatability extension of Betula platyphylla sap using lactic acid bacteria fermentation. J Korean Soc Food Sci Nutr, 38, 787-794

34. Kim ES, Song JH, Chung HY, Jeong HS, Jang HD, Kim GN (2012) Effect of fermentation with Lactobacillus plantarum and heat processing on the anti-oxidant activity and volatile composition of garlic. Food Eng Pro, 16, 374-380 